\title{
DETERMINATION OF BLACK SPOTS BY USING ACCIDENT EQUIVALENT NUMBER AND UPPER CONTROL LIMIT ON RURAL ROADS OF THAILAND
}

\author{
WANIT TREERANURAT (1) SUTHATHIP SUANMALI ${ }^{[}$
}

\begin{abstract}
A B S T R A C T
The Department of Rural Roads (DRR) is one of the highway authorities in Thailand responsible for over 48000 kilometres of rural roads and highway networks. One of its responsibilities is to provide better road safety management. In road safety procedures, black spots are usually identified by observing the frequency of accidents at a particular road section. This research aims to develop a model that includes levels of accident severity in the black spot identification process. The classification of severity levels includes fatalities, serious injuries, minor injuries, and damaged property only. The Analytic Hierarchy Process (AHP) is employed to derive the weight of each severity level. The identification model is developed using Equivalent Accident Number (EAN) and Upper Control Limit (UCL). The data applied in the model are obtained from the road accident investigation of DRR. Five roads - Nakhon Ratchasima 3052, Chonburi 1032, Nonthaburi 3021, Samutprakarn 2001 and Chiangmai 3029 - have been selected based on the top frequency accident recorded in the last three years. Based on the results of black spots identified in the study, most accidents occurred from frontal and rear-ended impacts due to exceeded speed limits. The article discusses recommendations.
\end{abstract}

KEY WORDS

black spot, equivalent accident number, road safety, rural roads

10.2478/emj-2021-0031
Suthathip Suanmali

TREC, Sirindhorn International Institute of Technology, Thammasat University, Thailand ORCID 0000-0001-7775-7384

Corresponding author: e-mail: ssuthathip@siit.tu.ac.th

Wanit Treeranurat

TREC, Sirindhorn International Institute of Technology,

Thammasat University, Thailand ORCID 0000-0001-6365-208X

\section{INTRODUCTION}

The number of road traffic fatalities worldwide continues to rise and has reached 1.35 million in 2016 (World Health Organization, 2018). Globally, this indicates nearly 3700 traffic fatalities every day, despite road safety procedures used in many countries. In low- and middle-income countries, the leading cause of traffic fatalities is road traffic crashes. In Thailand, traffic fatalities and injuries are still a major public health problem accounted for by road acci-

Treeranurat, W., \& Suanmali, S. (2021). Determination of black spots by using accident equivalent number and upper control limit on rural roads of Thailand. Engineering Management in Production and Services, 13(4), 57-71. doi: 10.2478/emj-20210031 
Tab. 1. Number of road traffic accidents, fatalities and injuries in Thailand

\begin{tabular}{|c|c|c|c|c|}
\hline \multirow{2}{*}{ YeAR } & \multicolumn{4}{|c|}{ NUMBER OF OCCURRENCES } \\
\cline { 2 - 5 } & ACCIDENTS & FATALITIES & INJURIES & $\begin{array}{c}\text { SERIOUS } \\
\text { INJURIES }\end{array}$ \\
\hline 2018 & 345234 & 10526 & 394588 & 2091 \\
\hline 2019 & 375964 & 10836 & 430788 & 2066 \\
\hline 2020 & 432647 & 9282 & 432647 & 1786 \\
\hline
\end{tabular}

Source: (Thai RSC - Road Accidents Data Center for Road Safety Culture, 2020).

dents. In 2016, Thailand ranked 8th among the countries worldwide with the highest number of road traffic fatalities from accidents, with 32.7 deaths for 100000 population per year. The numbers have remained virtually constant over the last ten years. The statistical data (Table 1) retrieved from the Road Accident Data Center for Road Safety Culture (ThaiRSC) consists of the number of accidents, fatalities and injuries in Thailand. The data collected from provinces of the country represent the increasing trend in the number of accidents and victims from 2018 to 2020.

The Department of Rural Roads (DRR) under the Ministry of Transportation (MOT) of Thailand is one of the highway authorities that develop and enhance road safety on rural roads and networks and reduce accidents and the number of victims. Road safety measures under the DRR include proactive and reactive measures to identify, reduce and improve road safety. Proactive measures focus on assessing road risk spots by using the Star Rating System (SRS) - one of the tools offered by the International Road Assessment Programme (IRAP). This tool requires many resources and systems to be integrated, which leads to high investments in many dimensions. For instance, road attributes must be collected, such as lane width, the number of lanes, skid resistance, median type etc. In addition, crash types are categorised and used as an important component to identify the road safety level; however, this is a preventive measure used by the DRR to inspect the road safety level. On the other hand, a traditional or reactive measure is based on road accident and crash frequency data. It aims to inspect road safety levels, i.e., identify black spots, without utilising road attributes and other available parameters.

A black spot is a road section with a high risk of a vehicle accident. The identification method considers an accident as a counted statistic record. Unlike a proactive measure, a reactive measure requires little resources and investments. According to the ORSA
(2017), the identification of a black spot location used by the DRR relies on the frequency of accidents as a parameter. Nevertheless, other collected parameters from accident sites, such as traffic volume, type of crash and road characteristics, have not been included in the identification process.

The reactive measure of identifying a black spot uses only the number of accidents and historical accident data (ORSA, 2017). With additional information collected from accident sites, the DRR has more valuable data and can develop a better system to identify black spots. One important collected parameter is the accident severity level. This parameter is related to the value of life and the economic value and has not been utilised as a parameter in the black spot identification. Hence, this research emphasised the development of an alternative method that includes the severity levels to identify black spots on rural roads and the network. The developed method was applied to five selected road networks, i.e., roads with a relatively high frequency of accidents. The accident data were collected by the highway authorities of the DRR from 2016-2018. This dataset consists of accident locations, the number of accidents and the severity levels, including victims involved. The parameters of interest or the severity levels are classified as fatalities and minor or major injuries.

\section{LITERATURE REVIEW}

The literature review focusses on reviewing the road safety evaluation method and its background information as well as the previous case study to support this research.

\subsection{BLACK SPOT DEFINITION AND IDENTIFI- CATION IN EUROPEAN AND OTHER COUNTRIES}

The hazardous, dangerous, or accident-prone locations are referred to as a black spot, which is a road section with a higher accident risk compared to others (ORSA, 2017; Kowtanapanich, 2007). In European countries, the black spot definition differs in many aspects. According to some authors (Elvik, 2007; Sorensen, 2007), the black spot definitions and identification in eight European countries are reviewed based on theoretical and best practice terms. Theoretical terms classify the black spot definition into numerical, statistical, and model-based (Elvik, 2007). The numerical definition is based on the accident number, accident rate and the combina- 
tion of accident number and rate. The statistical definition is based on the critical value of accident number and the critical value of accident rate. In addition, the model-based definition relies on the empirical Bayes and dispersion value. The extended work was made to produce the best practice guidelines (Sorensen, 2007) based on previous theoretical terms (Elvik, 2007), which contain the identification principles and methods for those eight countries.

The identification principles can be divided into accident-based and accident-unbased. The accidentbased principle includes other than model-based identification, which uses such parameters as the number of accidents, frequency and the rate of accidents. The model-based identification includes category analysis and accident-specific identification. The category analysis divided the set of an accident, road characteristics and traffic data into the pre-defined category to calculate the average number of accidents. The value of the average number of accidents will be used to compare with the expected number of accidents from a specific model, such as regression analysis or the empirical Bayes.

For the accident-unbased principle, quantitative and qualitative methods are used. These two methods focus on using road information, for instance, road geometry, surrounding environment, driving speed etc., instead of accident data. The summary of criteria to define a black spot, the identification principle, and the method used in eight European countries and Thailand are shown in Table 2.

Based on the above (Elvik, 2007), there is no recognised standard definition of a black spot. Still, in general, it could be determined as a site with a higher expected number of accidents than another site similar in terms of local risk factors. The number of accidents is the main parameter for traditional identification approaches in most reviewed cases. This is due to the independence of this parameter, which can be collected easily through an investigation without calculations or predictions. The suggested period for identification is a range between 3 and 5 years (Nguyen et al., 2016). The road analysis will focus on road sections determined based on the sliding window method, which allows dividing a road into sections to find the number of accidents in each. Based on reviews, the common sliding window can be between 100 - 1000 meters.

However, developing countries, specifically Southeast Asia, have data availability limitations. Hence, researchers have proposed multiple approaches to identifying black spots in this region.
In Vietnam(Nguyen et al., 2013), the criteria used for black spot identification is the number of accidents on a particular road and the damage severity. The severity levels are divided into three cases: two fatal accidents, three or more accidents and one fatal, and four or more accidents but no injury. The Black Spot Management (BSM) approach (Taneerananon et al., 2013) uses accident data to determine the blackspot site within a road network, which is a road section with poor safety performance, and classifies the road infrastructure as a black spot. This study includes a prioritised index by ranking blackspot sites using the safety potential in accident costs. The focused parameters in the study are the traffic volume, the accident severity and the accident cost rate.

In Myanmar (Mon, 2016), the combination of accident frequencies, the accident rate and the rate of quality control have been applied as the black spot identification procedure. The prioritisation or the black spot ranking is defined as the Danger Index (DI), and a site with the smallest DI is considered the most dangerous black spot. The required parameters in this research are mainly focused on the number of accidents, the accident rate and traffic volume.

Several authors (e.g. Susilo, 2016; Susilo et al., 2018; Halim \& Saing, 2018; Leuhery \& Hamkah, 2020) stated that Indonesia adopted the Equivalent Accident Number (EAN) method that determines the black spot location using the Weighted Accident Numbers (WAN) and the Upper Control Limit (UCL) as identification and ranking methods. The identification methods use such parameters as the number of accidents, accident severity levels. Such methods are used by many researchers in various areas of Indonesia. In addition, these methods do not require much investment and resources to prioritise black spots.

In Thailand, according to the ORSA (2017), previous research included various methods to determine black spots; for instance, the number of accidents method focusing on a location to identify the safety performance, the accident rate method that uses the number of accidents divided by the vehicle exposure to find the rate or their combination. The parameters and the number of accidents required for the accident number method have been summarised in research (Leelakajonjit \& Iamtrakul, 2013). The traffic volume and the number of accidents are required for the accident rate method. The modelbased identification requires all mentioned parameters. According to the ORSA (2017), the DRR employs the number of accidents method for the black spot identification defining a black spot as a location or 
Tab. 2. Black spot identification principle, method and criteria in eight European countries

\begin{tabular}{|c|c|c|c|c|c|}
\hline COUNTRY & $\begin{array}{l}\text { IDENTIFICATION } \\
\text { PRINCIPLE }\end{array}$ & $\begin{array}{l}\text { IDENTIFICATION AND } \\
\text { METHOD }\end{array}$ & $\begin{array}{l}\text { CRITERIA TO DEFINE } \\
\text { AS BLACK SPOT }\end{array}$ & $\begin{array}{l}\text { SLIDING WINDOW } \\
\text { (METER) }\end{array}$ & $\begin{array}{l}\text { IDENTIFication } \\
\text { Period (Year) }\end{array}$ \\
\hline Austria & $\begin{array}{l}\text { Combination of } \\
\text { Specific and Model } \\
\text { Based }\end{array}$ & $\begin{array}{l}\text { - Accident type } \\
\text { - Accident rate }\end{array}$ & $\begin{array}{l}\text { - } \geq 3 \text { similar injury } \\
\text { accidents within } \\
3 \text { years } \\
\text { - A relative coeffi- } \\
\text { cient }(\mathrm{Rk}) \geq 0.8\end{array}$ & 250 & 3 \\
\hline Denmark & $\begin{array}{l}\text { Combination of } \\
\text { Model Based and } \\
\text { Not Model Based }\end{array}$ & $\begin{array}{l}\text { - Poisson distribu- } \\
\text { tion } \\
\text { - Accident number }\end{array}$ & $\begin{array}{l}\text { - } 4 \text { accidents } \\
\text { within } 5 \text { years }\end{array}$ & $\begin{array}{l}\text { Fix length equal } \\
\text { to mean value of } \\
\text { mean number of } \\
\text { accidents }\end{array}$ & 5 \\
\hline Belgium & Not Model Based & - Accident number & $\begin{array}{l}\text { - } 5 \text { similar types of } \\
\text { accidents within } \\
1 \text { year } \\
\text { - } \geq 5 \text { injury ac- } \\
\text { cidents or } \geq 3 \\
\text { serious injury } \\
\text { accidents within } \\
3 \text { years }\end{array}$ & 100 & 1 or 3 \\
\hline Germany & $\begin{array}{l}\text { Combination of } \\
\text { Specific and not } \\
\text { Model Based }\end{array}$ & $\begin{array}{l}\text { - Accident type } \\
\text { - Accident number }\end{array}$ & $\begin{array}{l}\text { - } 5 \text { similar types of } \\
\text { accidents within } \\
1 \text { year } \\
\text { - } 5 \text { injury acci- } \\
\text { dents within } 3 \\
\text { years } \\
\text { - } 3 \text { serious injury } \\
\text { accidents within } \\
3 \text { years }\end{array}$ & - & 1 or 3 \\
\hline Hungary & Not Model Based & $\begin{array}{l}\text { - Accident number } \\
\text { - Accident rate }\end{array}$ & $\begin{array}{l}\text { - } \geq 4 \text { accidents } \\
\text { within } 3 \text { years } \\
\text { (Outside built-up } \\
\text { area) } \\
\text { - } \geq 4 \text { accidents } \\
\text { within } 3 \text { years } \\
\text { (Inside built-up } \\
\text { area) }\end{array}$ & $\begin{array}{r}100 \\
\text { or } \\
1000\end{array}$ & 3 \\
\hline Norway & Not Model Based & - Accident number & $\begin{array}{l}\text { - } \geq 4 \text { injury ac- } \\
\text { cidents within } 5 \\
\text { years }\end{array}$ & 100 & 5 \\
\hline Portugal & $\begin{array}{l}\text { Not Model Based } \\
\text { and } \\
\text { Model Based }\end{array}$ & $\begin{array}{l}\text { - Accident number } \\
\text { - Empirical Bayes }\end{array}$ & $\begin{array}{l}\text { - } \geq 5 \text { accidents } \\
\text { within } 1 \text { years on } \\
200 \text {-meter loca- } \\
\text { tion and severity } \\
\text { indicator } \geq 20\end{array}$ & 200 & 1 or 5 \\
\hline Switzerland & $\begin{array}{l}\text { Not Model Based } \\
\text { and } \\
\text { Model Based }\end{array}$ & $\begin{array}{l}\text { - Accident number } \\
\text { - Traditional } \\
\text { model }\end{array}$ & $\begin{array}{l}\text { Threshold value } \\
\text { of accident num- } \\
\text { ber and injury } \\
\text { accident number }\end{array}$ & - & 2 \\
\hline
\end{tabular}

site with a straight or curved road section or an intersection area with more than three accidents in three years. Based on research, the sliding window is 100 meters.

In Thai DRR, only the number of accidents is used as a parameter to identify black spots, but not the models employed by previously mentioned European countries. This is due to limited survey data of rural roads from the past years. The available parameters are only the number of accidents and the acci- dent severity level related to the victims. Thus, the lack of other parameters is the reason for this study to propose an identification method. The review of Indonesian research studies (e.g. Susilo et al., 2018; Halim \& Saing, 2018; Leuhery \& Hamkah, 2020) showed that EAN and UCL methods were supported by the department of transportation in Indonesia. The methods include such parameters as the number of accidents and accident severity levels. The result of black spot locations can be obtained using the EAN 
and UCL methods without requiring additional investment or resources. The combination of the number of accidents and severity levels has not yet been implemented in black spot identification. Hence, rather than focusing on the number of accidents only, the black spot identification model developed in this study emphasises the inclusion of accident severity levels. The developed model is expected to provide accurate black spots for the DRR and prioritise them for better road safety management for road users.

\subsection{Equivalent Accident Number (EAN)}

The EAN is known as a numeric economic scale to weigh the degree of accidents. The degree of accidents is then classified according to severity levels: Death (D), Serious or Severe Injury (SI), Minor Injury (MI) and Damaged Property Only (DPO). The accident numbers in each severity level then multiplied by the EAN value will become the Weighted Accident Numbers (WAN). The high value of WAN indicates that the road section must be fixed, or maintenance is Tab. 3. Equivalent accident number from previous research the top priority compared to the lower WAN value for other road sections. The WAN is used to prioritise the black spot locations. Rather than focus on the number of accidents as in the past, this method involves the life value of road users as a concerned parameter for identifying a black spot location. The weight for the EAN can be different due to the methodology used; the recommended EAN values from previous research are summarised in Table 3.

The WAN is the sum of the weighting value for a selected road, which can be seen in Equation 1 below.

\subsection{Upper Control Limit (UCL)}

To determine black spot location in this study using the statistical quality control chart, which is the Upper Control Limit (UCL) as shown in Equation 2.

Compared with the EAN, the road section that contains the WAN higher than the value of the UCL is defined as a black spot. Based on research (Sugiyanto et al., 2017), the value of probability factor $(\psi)$ is the probability that the accident rate is large enough so that the accident is not a random event, as shown

\begin{tabular}{|c|c|c|c|c|}
\hline \multirow[b]{2}{*}{ METHOD } & \multicolumn{4}{|c|}{ EQUIVALENT ACCIDENT NUMBER } \\
\hline & DEATH (D) & SERIOUS INJURY (SI) & MINOR INJURY (MI) & $\begin{array}{c}\text { DAMAGED PROPERTY } \\
\text { ONLY (DPO) }\end{array}$ \\
\hline \multirow{2}{*}{$\begin{array}{l}\text { Research } \\
\text { and Development Centre }\end{array}$} & 12 & 3 & 3 & 1 \\
\hline & \multicolumn{4}{|c|}{ (Engineering Committee for Standardization of Transportation Infrastructure, 2004) } \\
\hline \multirow{2}{*}{ Land Transportation } & 12 & 6 & 3 & 1 \\
\hline & \multicolumn{4}{|c|}{ (Soemitro \& Bahat, 2005) } \\
\hline \multirow{2}{*}{ Indonesian Police } & 10 & 5 & 1 & 1 \\
\hline & \multicolumn{4}{|c|}{ (Direktorat Jenderal Perhubungan Darat, 2007) } \\
\hline \multirow{2}{*}{$\begin{array}{l}\text { Accident Point Weightage } \\
\text { (APW) }\end{array}$} & 6 & 3 & 0.8 & 0.2 \\
\hline & \multicolumn{4}{|c|}{ (Wedasana, 2011) } \\
\hline \multirow{2}{*}{ Average of Rationalisation } & 10 & 4.25 & 2.33 & 1 \\
\hline & \multicolumn{4}{|c|}{ (Sugiyanto, Fadli, \& Santi, 2017) } \\
\hline
\end{tabular}

$$
\begin{aligned}
& W A N=E A N_{D} \times D+E A N_{S I} \times S I+ \\
& +E A N_{M I} \times M I+E A N_{D P O} \times D P O
\end{aligned}
$$

where:

WAN - Weight Accident Number,

$\mathrm{EAN}_{x}$ - Weight of each Degree of Accident; $x=\{\mathrm{D}, \mathrm{SI}, \mathrm{MI}, \mathrm{DPO}\}$,

D - Number of Deaths,

SI - Number of Serious Injuries,

MI - Number of Minor Injuries,

DPO - Number of Damaged Property Only equal to

Number of Accidents.

$$
U C L=\lambda+\psi x \sqrt{\left(\frac{\lambda}{m}+\frac{0.829}{m}+\left(\frac{1}{2} \times m\right)\right)}
$$

where:

$\lambda$ - Average Accident Score,

$\psi$ - Probability Factor,

$\mathrm{m}$ - Accident score in each section.

in Table 4. The most selected value of $\psi$ is $95 \%$ significance or 1.645 and $99.5 \%$ significance or 2.576 . 
Tab. 4. Probability tactor

\begin{tabular}{|c|c|c|c|c|c|}
\hline PROBABILITY & 0.005 & 0.0075 & 0.05 & 0.075 & 0.10 \\
\hline$\psi$ & 2.576 & 1.960 & 1.645 & 1.440 & 1.282 \\
\hline
\end{tabular}

\section{RESEARCH METHODS}

The structure and systematic activities were carried out with stages according to the scientific research. After obtaining the accident data, including accident severity levels, from the past three years recoded by the DRR, the weight of each severity level was determined using the analytic hierarchy process (AHP). Then, the EAN and UCL methods are applied to identify the black spots.

\subsection{ACCIDENT DATA}

The secondary data used in this study were retrieved by the Road Accident Investigation (RAI) team in the Department of Rural Roads, Thailand. The data consisted of road accidents on rural roads around the country during $2016-2018$, including the accident numbers and accident severity levels. 1472 roads had 4781 accidents that resulted in 1595 deaths (D), 1533 serious injuries (SI), 1653 minor injuries (MI) and the damaged property only (DPO).

\subsection{SEVERITY LEVEL AND THEIR WEIGHTS}

The severity levels of accidents can be divided into three categories: (1) death or fatal injury (D), (2) serious or major injury (SI), (3) minor or slight injury (MI). An accident without any injured victims is called an accident with material or property loss only or damaged property only (DPO). The death or fatal injury refers to accidents with fatalities on the spot or from an injury sustained with 30 days of the accident. An accident with a serious or major injury refers to a serious injury suffered by victims and in need of hospitalisation for over 30 days. A slight or minor injury requires first aid on-site or hospitalisation of fewer than 30 days.

To obtain the weight for the severity levels, the AHP is employed. It is one of the decision-making tools to deal with multi-criteria problems (Kim et al., 1999). By applying this method, the components of the decision-making problem are digested into a hierarchy of a top objective or goal, criteria, and sub-criteria layers. Then, the experts conduct a simple pairwise comparison by using a 9-point intensity among aspects in the structure, as shown in Table 5.
The objective of this AHP is to find the significance of each severity level (weight) that affects the identification of a black spot. The severity level in each group is considered as a criterion that must be compared. To illustrate further, an expert must compare a pair of severity levels, for instance, whether death or a serious injury has more impact in determining the road section as a black spot using the intensity level. According to Kim et al. (1999), the process of determining the weight includes forming a team of experts and assigning a pairwise comparison to the severity levels. A pairwise comparison matrix is then constructed by assigning a relative score for each pairwise comparison based on the numerical 9-point intensity levels. Then, the relative weight from each expert is evaluated, and the level of importance is obtained through normalisation. The calculation of the consistency ratio is also done to validate the results. Finally, the relative weight from the expert judgements is obtained by applying the geometric mean for all relative weights received from each expert.

The questionnaire survey was carried out at the Department of Rural Roads (DRR), Thailand, with a selection of experts who currently hold or previously held a leadership or management role in the areas of the black spot improvement or road safety audit. They must have experience in road safety audits or management for at least five years. They represent the road safety audit team. A total of 11 experts participated in the in-depth interview and responded to the AHP pairwise comparison. Based on research (Batagarawa et al., 2015), the number of experts was sufficient for the analysis. All definitions, such as

Tab. 5. 9-point intensity level

\begin{tabular}{|c|l|}
\hline $\begin{array}{c}\text { INTENSITY } \\
\text { LEVEL }\end{array}$ & \multicolumn{1}{c|}{ DeFINITION } \\
\hline 1 & Equal importance \\
\hline 2 & Equal to moderate importance \\
\hline 3 & Moderate importance \\
\hline 4 & Moderate to strong importance \\
\hline 5 & Strong importance \\
\hline 6 & Strong to very strong importance \\
\hline 7 & Very strong importance \\
\hline 8 & Very strong to extremely strong importance \\
\hline 9 & Extremely strong importance \\
\hline
\end{tabular}


severity and intensity levels, were clearly explained to experts. They were given the same set of questionnaire surveys during the interview session.

\subsection{DATA PREPARATION}

For the black spot identification, the roads were selected for the analysis based on the number of accidents, i.e., no less than ten accidents (Halim, 2018). Out of 54 roads with more than one accident, five roads were selected as they had the top five number of accidents. In this research, five roads were selected for the black spot identification: Nakhon Ratchasima 3052 (NRM 3052), Chonburi 1032 (CBR 1032), Nonthaburi 3021 (NBR 3021), Samut Prakarn 2001(SPK 2001) and Chiangmai 3029 (CM 3029). The black spot identification process suggested using accident data for 3 - 5 years (Elvik, 2007). Each road was then divided into sections of 100 meters in length, and the number of accidents in each section was calculated. There were $41,80,41,61$, and 159 road sections with at least one accident for NRM 3052, CBR 1032, NBR 3021, SPK 2001, and CM 3029, respectively. In addition, the types of accidents,

Tab. 6. Number of accidents according to types and causes of an accident

\begin{tabular}{|c|c|c|c|c|c|c|c|c|c|c|c|c|c|}
\hline \multirow[b]{2}{*}{ ROAD } & \multicolumn{7}{|c|}{ TYPES OF ACCIDENT } & \multicolumn{6}{|c|}{ CAUSES OF ACCIDENT } \\
\hline & $\stackrel{\mathscr{x}}{x}$ & 옾 & $\begin{array}{l}山 \\
\varpi \\
\infty \\
\leftarrow\end{array}$ & $\stackrel{\infty}{\underline{⺊}} \stackrel{0}{<}$ & ヘ̛ & ర & z & $\begin{array}{l}z \\
\text { zo }\end{array}$ & z్ & $\underset{\not 1}{z}$ & $\stackrel{\Upsilon}{>}$ & U & 点 \\
\hline NRM 3052 & 14 & 4 & 15 & 0 & 0 & 15 & 3 & 5 & 3 & 20 & 7 & 13 & 9 \\
\hline NBR 3021 & 22 & 0 & 22 & 5 & 0 & 31 & 13 & 2 & 2 & 43 & 38 & 4 & 4 \\
\hline CBR 1032 & 13 & 3 & 29 & 4 & 1 & 5 & 11 & 2 & 1 & 28 & 27 & 5 & 4 \\
\hline SPK 2001 & 15 & 1 & 144 & 101 & 8 & 3 & 3 & 1 & 0 & 0 & 270 & 4 & 0 \\
\hline CM 3029 & 9 & 0 & 219 & 7 & 0 & 89 & 19 & 43 & 16 & 13 & 203 & 60 & 4 \\
\hline Total & 73 & 8 & 433 & 113 & 9 & 143 & 49 & 53 & 22 & 104 & 545 & 86 & 21 \\
\hline
\end{tabular}

Tab. 7. Length, road properties and total number of accidents

\begin{tabular}{|c|c|c|c|}
\hline ROAD & $\begin{array}{c}\text { LENGTH } \\
\text { (KILOMETRES) }\end{array}$ & ROAD PROPERTIES & $\begin{array}{c}\text { TOTAL NUMBER OF ACCIDENTS } \\
(2016-2018)\end{array}$ \\
\hline NRM 3052 & 69.543 & $\begin{array}{l}\text { - } 2 \text { Lanes of straight sections } \\
\text { - } 3 \text { - and 4-Way Intersections } \\
\text { - Simple, compound and broken back curvature } \\
\text { - Residential area }\end{array}$ & 51 \\
\hline NBR 3021 & 31.102 & $\begin{array}{l}\text { - } 10 \text { Lanes of straight sections } \\
\text { - } 3 \text {-way Intersection with a traffic light } \\
\text { - Simple curvature } \\
\text { - } \text { Residential Area }\end{array}$ & 93 \\
\hline CBR 1032 & 12.492 & $\begin{array}{l}\text { - } 2 \text { Lanes of straight sections } \\
\text { - } 3 \text {-way Intersection without a traffic light } \\
\text { - Simple and broken back curvature } \\
\text { - Residential and industrial area }\end{array}$ & 66 \\
\hline SPK 2001 & 13.53 & $\begin{array}{l}\text { - } 6 \text { Lanes of straight sections } \\
\text { - } 3 \text {-way Intersection without a traffic light } \\
\text { - Simple and broken back curvature } \\
\text { - Residential and industrial area }\end{array}$ & 275 \\
\hline CM 3029 & 26.108 & $\begin{array}{l}\text { - } 6 \text { Lanes of straight sections } \\
\text { - } 3 \text {-way Intersection with a traffic light } \\
\text { - Simple and compound curvature } \\
\text { - } \text { Residential area }\end{array}$ & 343 \\
\hline \multicolumn{3}{|r|}{ TOTAL } & 828 \\
\hline
\end{tabular}


including Run-off-Road (RR), Head-On (HO), Frontal \& Rear-End (FT\&RE), Intersection \& Access Point (INT\&AP), Cross-Road (CR), Obstacle (OC) and Otherwise (OTW), and the causes of accidents including Drunkenness (DKN), Drowsiness (DSN), Recklessness (RLN), Violate Traffic Rule (VR), CrossCut (CC), Otherwise (OTW)) are summarised in Table 6 . The length, road properties and the total number of accidents are demonstrated in Table 7 . The example of a road divided based on the sliding-window method is shown in Table 8.

\subsection{BLACK SPOT IDENTIFICATION IN SELECTED ROADS}

Before applying EAN and UCL methods, the AHP results from 11 experts have led to weights for each severity level. It is referred to as EANx in Equation 1. Frequencies of accidents and severity levels for each road section (100 meters in length) were tallied. Then, the WAN value for each section was determined as indicated in Equation 1. The average accident $(\lambda)$ for each road was calculated as the total WAN values divided by the total number of sections

Tab. 8. Example of road sections for NRM 3052

\begin{tabular}{|c|c|c|c|c|}
\hline \multirow{2}{*}{$\begin{array}{c}\text { RoAd } \\
\text { SECtion } \\
\text { Number }\end{array}$} & \multicolumn{4}{|c|}{ FREQUENCY } \\
\hline & D & SI & MI & DPO \\
\hline 1 & 1 & 0 & 0 & 1 \\
\hline 2 & 0 & 0 & 1 & 1 \\
\hline 3 & 0 & 0 & 1 & 1 \\
\hline 4 & 0 & 0 & 0 & 1 \\
\hline 5 & 0 & 0 & 1 & 1 \\
\hline 6 & 0 & 0 & 1 & 1 \\
\hline 7 & 0 & 0 & 1 & 1 \\
\hline 8 & 0 & 0 & 1 & 2 \\
\hline 9 & 0 & 1 & 1 & 2 \\
\hline 10 & 0 & 0 & 1 & 2 \\
\hline 11 & 0 & 0 & 0 & 1 \\
\hline 12 & 0 & 0 & 2 & 1 \\
\hline 13 & 0 & 0 & 1 & 1 \\
\hline 14 & 0 & 0 & 1 & 1 \\
\hline 15 & 0 & 0 & 2 & 2 \\
\hline 16 & 0 & 0 & 2 & 1 \\
\hline 17 & 0 & 0 & 1 & 1 \\
\hline 18 & 0 & 0 & 1 & 1 \\
\hline 19 & 1 & 0 & 0 & 1 \\
\hline 20 & 0 & 1 & 0 & 1 \\
\hline 21 & 0 & 0 & 1 & 1 \\
\hline
\end{tabular}

with accidents. The UCL value for each road section was determined according to Equation 2. The last step was to compare WAN and UCL values within the same road section. If the WAN value exceeded the UCL, a black spot was identified.

\section{RESEARCH RESULTS}

\subsection{Prioritisation OF CRITERIA USING AHP}

The collected data from 11 experts were analysed using the AHP mentioned in section 2.2. The consistency ratio was less than 0.1 , which indicated that it was acceptable to use (Kim et al., 1999). The summary of the results is shown in Table 9. Then, to determine the relative weight of each severity, the geometric mean was applied. The relative weight results were 0.57 or 57 for death (D), 0.28 or 28 for serious injury (SI), 0.01 or 10 for minor injury (MI), and 0.05 or 5 for damaged property only (DPO), as indicated in Table 9. The experts prioritised between two severity levels and determined a score for each comparison using their scale. Experts evaluated which severity

\begin{tabular}{|c|c|c|c|c|}
\hline \multirow{2}{*}{$\begin{array}{c}\text { ROAD } \\
\text { SECtION } \\
\text { NUMBER }\end{array}$} & \multicolumn{4}{|c|}{ FREQUENCY } \\
\hline & D & SI & MI & DPO \\
\hline 22 & 0 & 1 & 0 & 1 \\
\hline 23 & 0 & 0 & 0 & 1 \\
\hline 24 & 0 & 0 & 2 & 1 \\
\hline 25 & 2 & 1 & 1 & 5 \\
\hline 26 & 0 & 0 & 1 & 1 \\
\hline 27 & 0 & 0 & 1 & 1 \\
\hline 28 & 0 & 0 & 2 & 1 \\
\hline 29 & 0 & 0 & 1 & 1 \\
\hline 30 & 0 & 0 & 1 & 1 \\
\hline 31 & 0 & 0 & 3 & 1 \\
\hline 32 & 0 & 1 & 0 & 1 \\
\hline 33 & 0 & 1 & 0 & 1 \\
\hline 34 & 0 & 1 & 1 & 2 \\
\hline 35 & 0 & 1 & 1 & 1 \\
\hline 36 & 0 & 0 & 1 & 1 \\
\hline 37 & 1 & 0 & 0 & 1 \\
\hline 38 & 0 & 0 & 1 & 1 \\
\hline 39 & 1 & 0 & 0 & 1 \\
\hline 40 & 0 & 0 & 1 & 1 \\
\hline 41 & 0 & 3 & 5 & 2 \\
\hline
\end{tabular}


Tab. 9. Relative weight based on expert decisions

\begin{tabular}{|c|r|r|r|r|}
\hline EXPERT & \multicolumn{1}{l|}{ D } & \multicolumn{1}{c|}{ SI } & \multicolumn{1}{c|}{ MI } & \multicolumn{1}{c|}{ DPO } \\
\hline 1 & 0.60 & 0.21 & 0.14 & 0.06 \\
\hline 2 & 0.57 & 0.28 & 0.09 & 0.05 \\
\hline 3 & 0.59 & 0.27 & 0.10 & 0.05 \\
\hline 4 & 0.48 & 0.36 & 0.10 & 0.06 \\
\hline 5 & 0.62 & 0.21 & 0.12 & 0.05 \\
\hline 6 & 0.59 & 0.25 & 0.10 & 0.06 \\
\hline 7 & 0.47 & 0.40 & 0.09 & 0.04 \\
\hline 8 & 0.56 & 0.29 & 0.09 & 0.06 \\
\hline 9 & 0.56 & 0.33 & 0.06 & 0.05 \\
\hline 10 & 0.63 & 0.23 & 0.10 & 0.04 \\
\hline 11 & 0.60 & 0.26 & 0.10 & 0.04 \\
\hline Relative Weight & 0.57 & 0.28 & 0.10 & 0.05 \\
\hline
\end{tabular}

level dominated over another in each comparison by determining the consequences and responsibilities that the highway authorities must bear in the case of accidents. The relative weight from experts demonstrated that the most important factor was the number of deaths from an accident. A high number of deaths from an accident implies some potential road safety standard problems. The weights obtained from the AHP identify the black spot location as equivalent accident number (EAN) values.

\subsection{BLACK SPOT IDENTIFICATION USING THE EAN AND THE UCL}

The weight accident number (WAN) for each road section was calculated, where the equivalent accident numbers (EAN) were 57, 28, 10 and 5 for death or fatal injury (D), serious or major injury (SI), slight or minor injury (MI), and damaged property only (DPO), respectively. The sum of WAN values was determined for each road and used to calculate the average value accident $(\lambda)$ by divining the WAN sum by the number of road sections with at least one accident, as summarised in Table 10.

The results of black spot locations are determined when the WAN value exceeds the UCL, arranging from the highest to the lowest WAN or severity values, as summarised in Tables 11, 12, 13, 14 and 15. In addition, Fig. 1 demonstrates the calculated WAN and UCL values for all road sections.

For further analysis, accidents at each black spot were investigated. The types and causes of accidents at each black spot were summarised in Tables 11 to 15.
Tab. 10. Total WAN value, the number of road sections and the average value accident

\begin{tabular}{|c|r|r|r|}
\hline ROAD & TOTAL WAN & \multicolumn{1}{|c|}{$\begin{array}{c}\text { NUMBER OF } \\
\text { ROAD SEC- } \\
\text { TIONS }\end{array}$} & $\begin{array}{c}\text { AVERAGE } \\
\text { VALUE } \\
\text { ACCIDENT }(\lambda)\end{array}$ \\
\hline NRM 3052 & 1315 & 41 & 32.07 \\
\hline NBR 3021 & 2029 & 80 & 25.36 \\
\hline CBR 1032 & 1661 & 41 & 40.51 \\
\hline SPK 2001 & 4514 & 61 & 74.00 \\
\hline CM 3029 & 9194 & 159 & 57.46 \\
\hline
\end{tabular}

As the study aimed to establish a black spot identification method for the DRR that included severity levels in addition to the number of accidents, the developed method used the existing severity data collected from the DRR road accident investigation team. Having different severity levels, black spots can be identified and prioritised by looking at the WAN. Larger WAN values indicate that a high priority should be placed on such locations. The highway authorities from the DRR participated in this study. The judgement of experts from the civil engineering group with experience in highway road safety audits pointed out that an accident involving deaths was the most significant parameter in identifying black spots. Based on the analysis, NMR 3052 has eight road sections with WAN values higher than the upper control limit boundaries; hence, they are classified as black spots. While the roads NBR 3021, CBR1032, SPK 2001 and CM 3029 have 25, 11, 15, and 49 black spots, respectively. The EAN and UCL methods were successful in identifying black spots and their rank based on the derivation from severity levels and accident frequencies.

From further investigation, the majority of accidents at black spots were frontal and rear-ended accidents due to exceeded speed limits. The surrounding areas of the selected roads were mostly residential. Road safety equipment should be installed to reduce accidents. For instance, rumble strips and additional speed-limit signs for road users.

\section{CONCLUSIONS}

In the past, the traditional approach focused on reducing the number of accidents by focusing only on accident frequencies at a particular road section. Identifying black spots by involving only frequencies of accidents at a particular road section may not be enough as it does not include severity levels, such as death or serious injury. Also, the focus should be on 
Tab. 11. Eight black spot locations on NRM 3052

\begin{tabular}{|c|c|c|c|c|c|c|c|c|c|c|c|c|c|c|c|c|c|c|c|}
\hline \multirow[b]{2}{*}{$\begin{array}{c}\text { ROAD } \\
\text { SECTION } \\
\text { NUMBER }\end{array}$} & \multicolumn{4}{|c|}{ FREQUENCY } & \multirow[b]{2}{*}{$\frac{2}{3}$} & \multirow[b]{2}{*}{ لِ } & \multicolumn{7}{|c|}{ TYPES OF ACCIDENT } & \multicolumn{6}{|c|}{ CAUSES OF ACCIDENT } \\
\hline & 0 & $\bar{n}$ & $\bar{\Sigma}$ & 윰 & & & $\stackrel{\varkappa}{\alpha}$ & 우 & 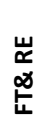 & $\begin{array}{l}\stackrel{0}{\leftarrow} \\
\infty \\
\llcorner\end{array}$ & ̛ & ¿ & z & ż & ž & $\underset{\not}{z}$ & $\stackrel{\Upsilon}{>}$ & U & 艿 \\
\hline 25 & 2 & 1 & 1 & 5 & 177 & 56.33 & & & 3 & & & 2 & & & & 2 & 3 & & \\
\hline 41 & 0 & 3 & 5 & 2 & 144 & 53.96 & & 1 & & & & 1 & & 1 & & & 1 & & \\
\hline 1 & 1 & 0 & 0 & 1 & 62 & 46.53 & & & 1 & & & & & & & & & & 1 \\
\hline 19 & 1 & 0 & 0 & 1 & 62 & 46.53 & 1 & & & & & & & & & 1 & & & \\
\hline 37 & 1 & 0 & 0 & 1 & 62 & 46.53 & & & & & & & 1 & & & & & 1 & \\
\hline 39 & 1 & 0 & 0 & 1 & 62 & 46.53 & 1 & & & & & & & & & & 1 & & \\
\hline 9 & 0 & 1 & 1 & 2 & 48 & 44.87 & 2 & & & & & & & 1 & & & 1 & & \\
\hline 34 & 0 & 1 & 1 & 2 & 48 & 44.87 & & & 2 & & & & & & & 1 & 1 & & \\
\hline & & & & & & TOTAL & 4 & 1 & 6 & 0 & 0 & 3 & 1 & 2 & 0 & 4 & 7 & 1 & 1 \\
\hline
\end{tabular}

Tab. 12. Fifteen black spot locations in NBR 3021

\begin{tabular}{|c|c|c|c|c|c|c|c|c|c|c|c|c|c|c|c|c|c|c|c|}
\hline \multirow[b]{2}{*}{$\begin{array}{c}\text { ROAD } \\
\text { SECTION } \\
\text { NUMBER }\end{array}$} & \multicolumn{4}{|c|}{ FREQUENCY } & \multirow[b]{2}{*}{$\frac{z}{4}$} & \multirow[b]{2}{*}{$\overrightarrow{\mathrm{J}}$} & \multicolumn{7}{|c|}{ TYPES OF ACCIDENT } & \multicolumn{6}{|c|}{ CAUSES OF ACCIDENT } \\
\hline & 0 & $\bar{n}$ & $\bar{\Sigma}$ & 움 & & & $\stackrel{\sim}{\sim}$ & 우 & $\begin{array}{l}\underset{\leftarrow}{\varpi} \\
\underset{\leftarrow}{L}\end{array}$ & $\begin{array}{l}\frac{a}{4} \\
\infty \\
上\end{array}$ & 뚜 & ర & 点 & $\begin{array}{l}z \\
\text { 酋 }\end{array}$ & ำ & $\underset{\not z}{z}$ & $\stackrel{\Upsilon}{>}$ & u & 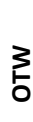 \\
\hline 28 & 2 & 2 & 1 & 1 & 185 & 50.15 & & & & & & 1 & & & & 1 & & & \\
\hline 31 & 1 & 1 & 3 & 2 & 125 & 45.76 & & & & & & 1 & & & & & 1 & & \\
\hline 46 & 1 & 1 & 1 & 1 & 100 & 43.62 & & & & & & 1 & & & & & 1 & & \\
\hline 68 & 1 & 1 & 0 & 1 & 90 & 42.69 & 1 & & & & & & & & & 1 & & & \\
\hline 25 & 1 & 0 & 2 & 1 & 82 & 41.92 & & & 1 & & & & & 1 & & & & & \\
\hline 48 & 0 & 2 & 2 & 1 & 81 & 41.82 & & & & & & 1 & & & & 1 & & & \\
\hline 50 & 1 & 0 & 1 & 2 & 77 & 41.41 & 1 & & & & & & & & & 1 & & & \\
\hline 55 & 1 & 0 & 0 & 2 & 67 & 40.35 & 1 & & & & & & & & & 1 & & & \\
\hline 47 & 1 & 0 & 0 & 1 & 62 & 39.8 & & & & & & & 1 & & & & 1 & & \\
\hline 58 & 1 & 0 & 0 & 1 & 62 & 39.8 & 1 & & & & & & & & & 1 & & & \\
\hline 34 & 0 & 2 & 0 & 1 & 61 & 39.68 & & & & & & 1 & & & & & 1 & & \\
\hline 40 & 0 & 1 & 1 & 3 & 53 & 38.74 & & & & & & 1 & & & & 1 & & & \\
\hline 38 & 0 & 0 & 4 & 2 & 50 & 38.37 & & & & & & 1 & & & & 1 & & & \\
\hline 39 & 0 & 0 & 4 & 1 & 45 & 37.73 & & & & & & 1 & & & & & 1 & & \\
\hline 67 & 0 & 0 & 3 & 2 & 40 & 37.06 & 1 & & & & & & & & & 1 & & & \\
\hline & & & & & & Total & 5 & 0 & 1 & 0 & 0 & 8 & 1 & 1 & 0 & 9 & 5 & 0 & 0 \\
\hline
\end{tabular}


Tab. 13. Eleven black spot locations in CBR 1032

\begin{tabular}{|c|c|c|c|c|c|c|c|c|c|c|c|c|c|c|c|c|c|c|c|}
\hline \multirow[b]{2}{*}{$\begin{array}{c}\text { ROAD } \\
\text { SECTION } \\
\text { NUMBER }\end{array}$} & \multicolumn{4}{|c|}{ FREQUENCY } & \multirow[b]{2}{*}{$\frac{2}{3}$} & \multirow[b]{2}{*}{ لِ } & \multicolumn{7}{|c|}{ TYPES OF ACCIDENT } & \multicolumn{6}{|c|}{ CAUSES OF ACCIDENT } \\
\hline & 0 & $\bar{n}$ & $\bar{\Sigma}$ & 윰 & & & $\stackrel{\mathscr{c}}{\widetilde{\alpha}}$ & 오 & $\begin{array}{l}\underset{\sim}{\varpi} \\
\underset{L}{\varnothing}\end{array}$ & 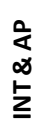 & 또 & பั & 点 & 立 & zू & $\underset{\sim}{\underline{x}}$ & $\stackrel{n}{>}$ & U & 点 \\
\hline 1 & 0 & 5 & 0 & 2 & 150 & 62.86 & & & 2 & & & & & & & 1 & & 1 & \\
\hline 14 & 1 & 3 & 0 & 1 & 146 & 62.56 & & 1 & & & & & & & & 1 & & & \\
\hline 29 & 1 & 1 & 0 & 3 & 100 & 58.8 & & & 1 & & & 1 & 1 & & & 2 & 1 & & \\
\hline 6 & 0 & 1 & 5 & 4 & 98 & 58.62 & & & 3 & & 1 & 1 & & & & 1 & 2 & 1 & 1 \\
\hline 17 & 0 & 1 & 4 & 5 & 93 & 58.16 & 2 & & 2 & & & & 1 & 1 & & 1 & 1 & 1 & 1 \\
\hline 23 & 0 & 1 & 4 & 4 & 88 & 57.69 & 1 & & 2 & & & 1 & & & & 2 & 2 & & \\
\hline 18 & 1 & 0 & 1 & 2 & 77 & 56.6 & & 1 & & & & & 1 & 1 & & & 1 & & \\
\hline 37 & 0 & 1 & 3 & 3 & 73 & 56.19 & & & 1 & & & & 2 & & & 1 & 2 & & \\
\hline 12 & 1 & 0 & 0 & 1 & 62 & 55 & & & & & & 1 & & & & & 1 & & \\
\hline 40 & 1 & 0 & 0 & 1 & 62 & 55 & & & 1 & & & & & & & 1 & & & \\
\hline 7 & 0 & 0 & 4 & 3 & 55 & 54.2 & 1 & & & & & 1 & 1 & & & & 1 & 1 & \\
\hline & & & & & & Total & 4 & 2 & 12 & 0 & 1 & 5 & 6 & 2 & 0 & 10 & 11 & 4 & 2 \\
\hline
\end{tabular}

Tab. 14. Fifteen black spot locations in SPK 2001

\begin{tabular}{|c|c|c|c|c|c|c|c|c|c|c|c|c|c|c|c|c|c|c|c|}
\hline \multirow[b]{2}{*}{$\begin{array}{c}\text { ROAD } \\
\text { SECTION } \\
\text { NUMBER }\end{array}$} & \multicolumn{4}{|c|}{ FREQUENCY } & \multirow[b]{2}{*}{$\underset{3}{z}$} & \multirow[b]{2}{*}{ ป઼ } & \multicolumn{7}{|c|}{ TYPES OF ACCIDENT } & \multicolumn{6}{|c|}{ CAUSES OF ACCIDENT } \\
\hline & 0 & n & $\bar{\Sigma}$ & 윰 & & & $\stackrel{\mathscr{c}}{\widetilde{x}}$ & 오 & 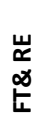 & $\begin{array}{l}\stackrel{a}{\alpha} \\
\infty \\
\vdots\end{array}$ & 뚠 & ¿ & z & Z & ż & $\underset{\not \vec{x}}{z}$ & $\stackrel{n}{>}$ & U & 文 \\
\hline 32 & 1 & 0 & 23 & 25 & 412 & 110.98 & 1 & & 8 & 15 & & & 1 & & & & 25 & & \\
\hline 29 & 0 & 0 & 27 & 26 & 400 & 110.44 & 2 & & 10 & 13 & 1 & & & & & & 26 & & \\
\hline 11 & 0 & 0 & 21 & 21 & 315 & 106.35 & 1 & & 15 & 4 & 1 & & & & & & 21 & & \\
\hline 14 & 0 & 0 & 14 & 15 & 215 & 100.75 & 1 & & 7 & 5 & 1 & & & & & & 15 & & \\
\hline 17 & 0 & 0 & 14 & 15 & 215 & 100.75 & & & 1 & 14 & & & & & & & 15 & & \\
\hline 39 & 0 & 0 & 16 & 9 & 205 & 100.12 & 1 & & 4 & 4 & & & & & & & 9 & & \\
\hline 12 & 0 & 0 & 13 & 14 & 200 & 99.8 & 1 & & 8 & 2 & 1 & & 1 & & & & 13 & 1 & \\
\hline 15 & 0 & 0 & 12 & 15 & 195 & 99.48 & & & 10 & 2 & 2 & & & & & & 14 & & \\
\hline 36 & 0 & 0 & 11 & 9 & 155 & 96.74 & 1 & & 6 & 2 & & & & & & & 9 & & \\
\hline 40 & 1 & 1 & 3 & 5 & 140 & 95.63 & & 1 & 1 & 3 & & & & & & & 4 & 1 & \\
\hline 55 & 0 & 0 & 9 & 10 & 140 & 95.63 & 1 & & 3 & 6 & & & & & & & 10 & & \\
\hline 54 & 2 & 0 & 0 & 2 & 124 & 94.38 & & & 2 & & & & & & & & 1 & 1 & \\
\hline 59 & 2 & 0 & 0 & 1 & 119 & 93.97 & & & 1 & & & & & & & & 1 & & \\
\hline 16 & 1 & 0 & 2 & 5 & 102 & 92.52 & & & 2 & & 1 & 2 & & & & & 5 & & \\
\hline 5 & 1 & 1 & 1 & 1 & 100 & 92.35 & & & & & & & 1 & & & & 1 & & \\
\hline & & & & & & Total & 9 & 1 & 78 & 70 & 6 & 2 & 3 & 0 & 0 & 0 & 169 & 3 & 0 \\
\hline
\end{tabular}


Tab. 15. Forty-nine black spot locations in CM 3029

\begin{tabular}{|c|c|c|c|c|c|c|c|c|c|c|c|c|c|c|c|c|c|c|c|}
\hline \multirow[b]{2}{*}{$\begin{array}{c}\text { ROAD } \\
\text { SECTION } \\
\text { NUMBER }\end{array}$} & \multicolumn{4}{|c|}{ FREQUENCY } & \multirow[b]{2}{*}{$\begin{array}{l}z \\
3\end{array}$} & \multirow[b]{2}{*}{ ป઼ } & \multicolumn{7}{|c|}{ TYPES OF ACCIDENT } & \multicolumn{6}{|c|}{ CAUSES OF ACCIDENT } \\
\hline & 0 & দ & $\bar{\Sigma}$ & 윰 & & & $\stackrel{\mathscr{c}}{\propto ⿻}$ & 오 & 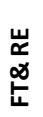 & $\begin{array}{l}\stackrel{2}{\varangle} \\
\infty \\
⺊\end{array}$ & ษ์ & ¿ & 孞 & $\begin{array}{l}z \\
\text { zo }\end{array}$ & zู & $\underset{\not \supset}{z}$ & $\stackrel{\mathscr{c}}{>}$ & U & 苜 \\
\hline 65 & 2 & 3 & 15 & 9 & 393 & 93.57 & & & 8 & & & & 1 & 1 & & & 2 & 6 & \\
\hline 151 & 0 & 0 & 18 & 18 & 270 & 87.39 & & & 7 & 1 & & & & & & & 7 & 1 & \\
\hline 17 & 0 & 2 & 16 & 10 & 266 & 87.17 & & & 6 & 1 & & 1 & & & & 2 & 2 & 6 & \\
\hline 31 & 1 & 0 & 8 & 4 & 157 & 80.28 & & & 4 & & & & & & & & 4 & & \\
\hline 152 & 2 & 0 & 3 & 2 & 154 & 80.06 & & & 2 & & & & & 1 & & & 1 & & \\
\hline 117 & 1 & 2 & 3 & 2 & 153 & 79.99 & & & 1 & & & 1 & & 1 & & & 1 & & \\
\hline 145 & 0 & 1 & 10 & 5 & 153 & 79.99 & & & 5 & & & & & & & & 4 & & \\
\hline 15 & 1 & 1 & 4 & 3 & 140 & 79.01 & & & 3 & & & & & & & & 3 & & \\
\hline 33 & 0 & 3 & 3 & 5 & 139 & 78.93 & & & 5 & & & & & & & & 3 & 2 & \\
\hline 48 & 2 & 0 & 1 & 2 & 134 & 78.54 & & & 1 & & & 1 & & & & & 2 & & \\
\hline 24 & 0 & 0 & 11 & 4 & 130 & 78.23 & 1 & & 3 & & & & & & & & 4 & & \\
\hline 49 & 1 & 0 & 5 & 4 & 127 & 77.99 & & & 4 & & & & & & & 1 & 5 & & \\
\hline 20 & 0 & 2 & 5 & 4 & 126 & 77.9 & & & 4 & & & & & & & & 2 & 2 & \\
\hline 83 & 0 & 1 & 6 & 7 & 123 & 77.66 & & & 2 & & & 2 & & & & & 4 & & \\
\hline 71 & 0 & 0 & 9 & 6 & 120 & 77.41 & & & 6 & & & & & & & & & 5 & \\
\hline 144 & 0 & 1 & 7 & 4 & 118 & 77.25 & & & 3 & & & & 1 & & & & 2 & 2 & \\
\hline 133 & 1 & 0 & 3 & 5 & 112 & 76.74 & & & & & & 5 & & & 2 & & 3 & & \\
\hline 8 & 1 & 1 & 1 & 2 & 105 & 76.12 & 1 & & & & & & 1 & 1 & & & 1 & & \\
\hline 23 & 0 & 0 & 8 & 5 & 105 & 76.12 & & & 2 & 1 & & 2 & & 1 & & & 4 & & \\
\hline 42 & 0 & 0 & 9 & 3 & 105 & 76.12 & & & 2 & & & & 1 & & & & 3 & & \\
\hline 139 & 1 & 1 & 1 & 2 & 105 & 76.12 & & & 1 & & & 1 & & & & & 2 & & \\
\hline 114 & 0 & 1 & 6 & 3 & 103 & 75.95 & & & 3 & & & & & & 3 & & & & \\
\hline 14 & 0 & 1 & 5 & 4 & 98 & 75.49 & 1 & & 3 & & & & & & 2 & & 2 & & \\
\hline 36 & 0 & 1 & 5 & 4 & 98 & 75.49 & & & 2 & & & 2 & & & & & 1 & 3 & \\
\hline 121 & 1 & 0 & 3 & 2 & 97 & 75.4 & & & 1 & & & 1 & & 1 & & & 1 & & \\
\hline 128 & 1 & 0 & 3 & 2 & 97 & 75.4 & & & 1 & & & 1 & & & & & & 2 & \\
\hline 119 & 0 & 1 & 5 & 3 & 93 & 75.03 & & & 3 & & & & & & & & 2 & 1 & \\
\hline 135 & 0 & 1 & 5 & 3 & 93 & 75.03 & & & 3 & & & & & 1 & 1 & & 1 & & \\
\hline 11 & 1 & 0 & 2 & 3 & 92 & 74.93 & & & & & & 2 & 1 & 1 & & & 2 & & \\
\hline 9 & 0 & 2 & 2 & 3 & 91 & 74.84 & 1 & & & & & 1 & 1 & 1 & 2 & & & & \\
\hline 72 & 0 & 0 & 7 & 4 & 90 & 74.74 & & & 3 & & & 1 & & & & & 3 & 1 & \\
\hline 10 & 0 & 1 & 4 & 4 & 88 & 74.55 & & & 1 & & & 3 & & 1 & 1 & & 1 & & \\
\hline 19 & 1 & 0 & 2 & 2 & 87 & 74.45 & & & 2 & & & & & & & & 2 & & \\
\hline 40 & 0 & 0 & 7 & 3 & 85 & 74.25 & & & 3 & & & & & 2 & & & 1 & & \\
\hline 46 & 0 & 0 & 6 & 5 & 85 & 74.25 & & & 2 & & & 3 & & 2 & & & 2 & 1 & \\
\hline 104 & 0 & 1 & 4 & 3 & 83 & 74.05 & & & & 2 & & 1 & & 1 & & & 2 & & \\
\hline 52 & 1 & 0 & 2 & 1 & 82 & 73.95 & & & 1 & & & & & 1 & & & & & \\
\hline 70 & 0 & 0 & 6 & 4 & 80 & 73.75 & & & 3 & & & 1 & & 1 & & & 2 & & 1 \\
\hline 103 & 0 & 0 & 6 & 4 & 80 & 73.75 & & & 4 & & & & & 2 & & 1 & 1 & & \\
\hline
\end{tabular}




\begin{tabular}{|c|c|c|c|c|c|c|c|c|c|c|c|c|c|c|c|c|c|c|c|}
\hline \multirow[b]{2}{*}{$\begin{array}{c}\text { ROAD } \\
\text { SECTION } \\
\text { NUMBER }\end{array}$} & \multicolumn{4}{|c|}{ FREQUENCY } & \multirow[b]{2}{*}{$\underset{3}{z}$} & \multirow[b]{2}{*}{ ل् } & \multicolumn{7}{|c|}{ TYPES OF ACCIDENT } & \multicolumn{6}{|c|}{ CAUSES OF ACCIDENT } \\
\hline & 0 & $\bar{n}$ & $\bar{\Sigma}$ & 움 & & & $\stackrel{\mathscr{c}}{\sim}$ & 우 & $\begin{array}{l}\underset{\sim}{山} \\
\underset{L}{L}\end{array}$ & 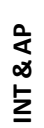 & 뚠 & ૫ & $\underset{1}{3}$ & $\begin{array}{l}z \\
\text { zo }\end{array}$ & ž & $\underset{\not \supset}{z}$ & $\stackrel{\Upsilon 1}{>}$ & U & $\sum_{0}^{3}$ \\
\hline 7 & 0 & 1 & 4 & 2 & 78 & 73.55 & & & 1 & & & 1 & & & & & 1 & 1 & \\
\hline 62 & 0 & 1 & 4 & 2 & 78 & 73.55 & & & 1 & & & 1 & & & & & 1 & 1 & \\
\hline 75 & 0 & 1 & 4 & 2 & 78 & 73.55 & & & 1 & 1 & & & & 1 & & & 1 & & \\
\hline 154 & 0 & 1 & 4 & 2 & 78 & 73.55 & & & 1 & & & & 1 & & & & 2 & & \\
\hline 54 & 1 & 0 & 1 & 2 & 77 & 73.44 & & & 1 & & & 1 & & 1 & & & 1 & & \\
\hline 73 & 1 & 0 & 1 & 2 & 77 & 73.44 & & & 1 & & & 1 & & & & & 2 & & \\
\hline 112 & 1 & 0 & 1 & 2 & 77 & 73.44 & & & 1 & & & 1 & & 1 & & & 1 & & \\
\hline 126 & 0 & 0 & 6 & 3 & 75 & 73.23 & & & 3 & & & & & 1 & & & & 2 & \\
\hline 137 & 0 & 0 & 7 & 1 & 75 & 73.23 & & & 1 & & & & & & & & 1 & & \\
\hline 158 & 0 & 0 & 6 & 3 & 75 & 73.23 & & & 2 & & & & 1 & & & & 2 & 1 & \\
\hline & & & & & & Total & 4 & 0 & 117 & 6 & 0 & 34 & 8 & 23 & 11 & 4 & 90 & 37 & 1 \\
\hline
\end{tabular}
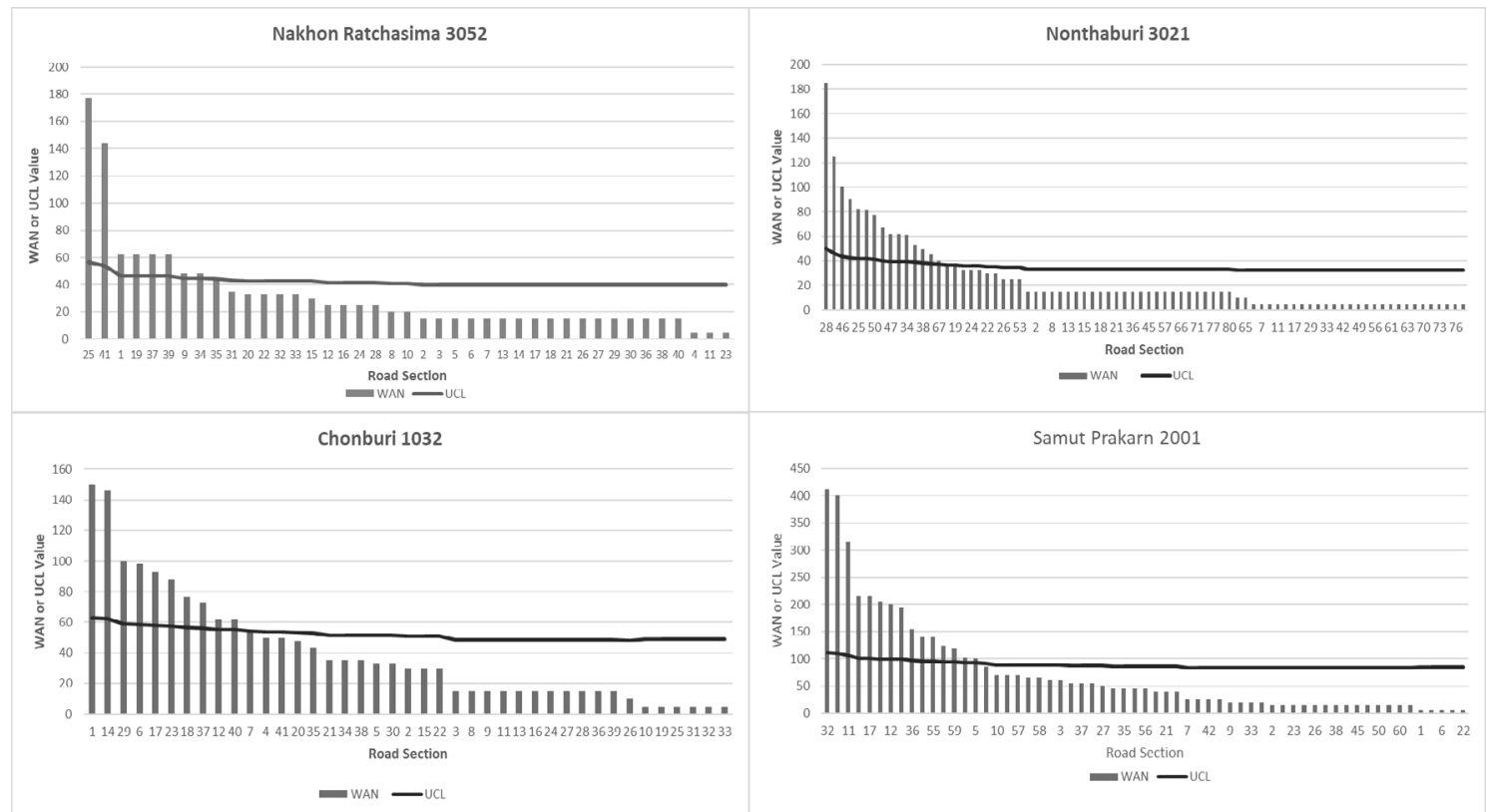

Chiangmai 3029

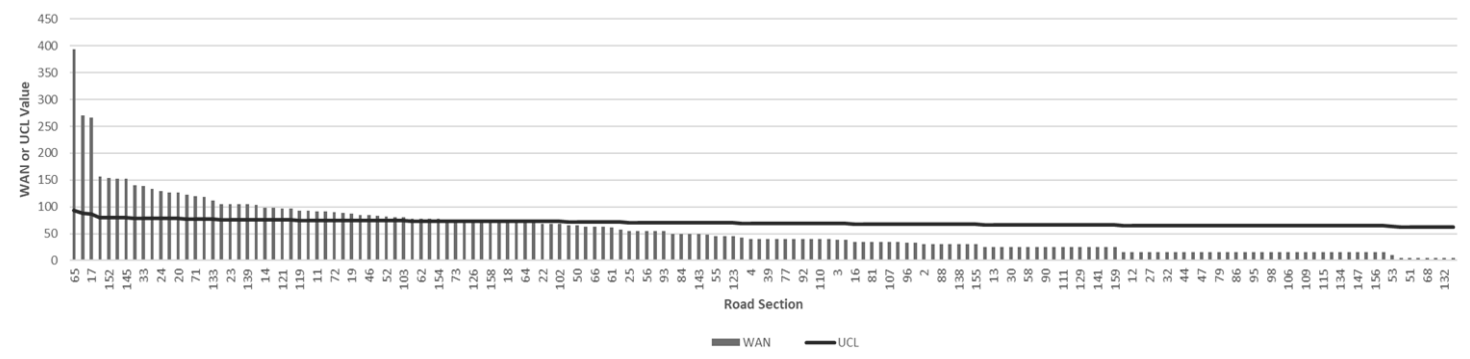

Fig. 1. Black spot identification with UCL boundaries on all sampled roads 
a road section with accidents resulting in injuries or fatalities. Hence, the developed method that includes different severity levels should give the highway authorities a better perspective of black spots. For instance, in the case of road section 25 on SPK 3021, the number of accidents in the past three years was four, with two minor injuries recorded. However, based on the traditional accident frequency approach, the section is considered a black spot since the frequency is above three. Once severity levels are considered, the result of this developed model yields the EAN value of less than the UCL. Hence, using this research method, such a section is not a black spot even though it had more than three accidents. On the other hand, two accidents occurred in road section 54 on SPK 3021 in the past three years. This road section is not considered a black spot when using a traditional approach. However, these accidents resulted in two deaths. Thereby, when using the EAN approach and considering the severity levels in the calculation, the EAN is much greater than the UCL. As a result, it is a black spot, and has a high priority to be fixed or reworked to make sure it can maintain the standard of road safety. The most critical black spots are those listed based on WAN values. Once the critical or true black spot is identified, the DRR can prioritise the road for safety improvement. With accurate identification of black spots, effective road safety plans and budgets can be organised. Once safety measures are applied to black spots, road users can travel safer, and the number of injuries or fatalities are expected to decrease. This implies that in socioeconomic terms, the cost of an accident based on fatalities, for instance, cost of productivity loss or human cost and property damage cost, will also decrease.

The identification and prioritisation by using the EAN on rural roads of Thailand are applicable to use, and the generated results are acceptable. The proposed model does not require many additional parameters or investments. The added parameters can be obtained easily by requiring such detailed records of accidents with their classification of severity levels.

The limitation of this study is that the weight was obtained based on the decision of experts in Thailand. In addition, the weight for damaged property only is rather low when compared to other parameters; this infers that the experts believe that the influence of the property damage is relatively low. In addition, accident types and causes in the secondary data only provided four types of severity levels. If other organisations have different databases and severity levels, the black spot identification process for each organisation can be adjusted by adding or removing the parameters mentioned in this research.

\section{ACKNOWLEDGEMENTS}

The publication of the article for 11th International Conference on Engineering, Project, and Production Management - EPPM2021 was financed in the framework of the contract no. DNK/ SN/465770/2020 by the Ministry of Science and Higher Education within the "Excellent Science" programme.

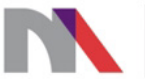

Ministry of Science and Higher Education Republic of Poland

\section{LITERATURE}

Batagarawa, R., Williams, J., Potts, J., \& Brown, J. (2015). Use of Analytic Hierarchy Process (AHP) as an Instrument to Develop a Solid Waste Management Assessment Tool. Global Journal of Advanced Engineering Technologies, 4(2), 70-75.

Chiangmai University. (2018). The Development of Road Safety Audits System for Department of Rural Roads Thailand. Thailand: Department of Rural Roads.

Direktorat Jenderal Perhubungan Darat. (2007). Pedoman Operasi Accident Black Spot Investigation Unit/Unit Penelitian Kecelakaan Lalu Lintas (ABIU/UPK). Jakarta: Ministry of Transportation Republic of Indonesia. doi: 10.15294/jtsp.v19i2.10768

Elvik, R. (2007). State-of-the-Art Approaches to Road Accident Black Spot Management and Safety Analysis of Road Networks. Oslo: The Institue of Transport Economics (TOI).

Engineering Committee for Standardization of Transportation Infrastructure. (2004). Handling Location of Traffic Accident. Department of Settlement and Regional Infrastructure. Jakarta: Department of Settlement and Regional Infrastructure.

Halim, H., \& Saing, Z. (2018). Severity Characteristics and Identification of Traffic Accident Prone Areas in Makassar City. Journal of Advanced Research in Dynamical and Control Systems, 10, 2134-2141.

Kim, K., Bernardin, V., Bernardin, L., \& Associates. (1999). Application of an Analytical Hierarchy Process at the Indiana Department of Transportation for Prioritizing Major Highway Capital Investments. In R. Donnelly (Ed.), The Seventh TRB Conference on the Applications of Transportation Planning Methods, (pp. 266-273). Boston.

Kowtanapanich, W. (2007). Black Spot Identification Methods in Thailand. Chulachomklao Royal Military Academy Journal, 126-134. 
Leelakajonjit, A., \& Iamtrakul, P. (2013). Appropriated Accident Black Spot Definition for Thai Police. The National Convention on Civil Engineering. Chiangmai.

Leuhery, L., \& Hamkah, H. (2020). Determination of Black Site Area Based on Equivalent Accident Number Analysis: Case Study National Roads in Ambon City. Civil Engineering and Architecture, 1063-1073.

Mon, C. (2016). Identiyfying Harzadous Locations based on Expected Crash Frequency on Yangon-Mandalay Expressway in Myanmar. Retrieved from http://sutir. sut.ac.th:8080/jspui/handle/123456789/6201

Nguyen, H. H., Taneerananon, P., \& Luathep, P. (2016). Approach to Identifying Black Spots Based on Potential Saving in Accident Costs. Engineering Journal, 10(2), $110-122$

Nguyen, X. D., Pham, H. S., Chu, M. H., \& Nguyen, H. D. (2013). Vietnam Road Black-spot Evaluation by Accident Schema: Pilot Study for a Sub-urban Area of Hanoi. The Eastern Asia Society for Transportation Studies. Hanoi. doi: 10.13189/cea.2020.080533

Office of Road Safety Audits (ORSA). (2017). Road Safety Principle Manual. Bangkok: Department of Rural Roads Thailand.

Soemitro, R. A., \& Bahat, Y. S. (2005). Accident Analysis Assessment Factors Influence to The Accident on Traffic Safety Improvement (Case: PalangkarayaTangkiling National Road). Eastern Asia Society for Transportation Studies. Eastern Asia Society for Transportation Studies, 5, 2091-2105.

Sugiyanto, G., Fadli, A., \& Santi, M. Y. (2017). Identification of Black Spot and Equivalent Accident Number Using Upper Control Limit Method. ARPN Journal of Engineering and Applied Sciences, 12, 528-535.

Susilo, B. H. (2016). Guideline for Survey, Investigation, and Design of Black Spot Location (SID-BSL) and Its Application in Lampung Province, Indonesia. Civil Engineering Dimension, 18, 49-56. doi: 10.9744/ ced.18.1.49-56

Susilo, B. H., Geovan, R., \& Imanuel, I. (2018). Identifying Black Spots in Southeast Sulawesi Province, Indonesia: A Combination Method of Equivalent Accident Number and Road Safety Survey Value. 11th Asia Pacific Transportation and the Environment Conference (APTE 2018). doi: 10.2991/apte-18.2019.28

Taneerananon, P., Lamtrakul, P., Koren, C., \& Nguyen, H. (2013). The Significance of Developing A New Black Spot Safety Management Approach for The Local Road Traffic Nature of Ho Chi Minh City. Acta Technica Jaurinensis, 6(2), 91-106.

Thai RSC - Road Accidents Data Center for Road Safety Culture. (2020). Thai RSC - Road Accidents Data Center for Road Safety Culture. (Road Accident Victims Protection Company Limited) Retrieved from http://rvpreport.rvpeservice.com/viewrsc. aspx? report $=0486 \&$ session $=16$

Wedasana, A. S. (2011). Analysis of Accident-Prone Areas and Compilation of Databases based on Geographical Information Systems (Case Study of Denpasar City). Indonesia: Universitas Udayana.
Xiaolan, Z., Hong, X., \& Huiping, Y. (2013). Determination of the Weight Values of Assessment Indexes of Website Based on AHP - Take the Website of University Library as an Example. International Conference on Computational and Information Sciences, 652-655. doi: 10.1109/ICCIS.2013.177 